\title{
Pengaruh Bahan Invigorasi dan Lama Perendaman Pada Benih Padi (Oryza sativa L.) Kadaluarsa Terhadap Viabilitas dan Vigor Benih
}

\author{
The Effect of Invigorating Material and Soaking Periods on Expired Rice Seeds \\ (Oryza sativa L.) againts Viability and Vigor Seeds \\ Resti Afdharani ${ }^{1}$, Bakhtiar ${ }^{* 1}$, Hasanuddin ${ }^{* 1}$ \\ ${ }^{1}$ Mahasiswa Program Studi Agroteknologi, Fakultas Pertanian, Universitas Syiah Kuala \\ ${ }^{*}$ Staf Dosen Program Studi Agroteknologi, Fakultas Pertanian, Universitas Syiah Kuala
}

\begin{abstract}
Abstrak. Penelitian ini bertujuan untuk mengetahui pengaruh bahan invigorasi dan lama perendaman serta interaksi keduanya terhadap viabilitas benih padi kadaluarsa. Penelitian ini dilaksanakaan di Laboratorium Ilmu dan Teknologi Benih Jurusan Agroteknologi Fakultas Pertanian Universitas Syiah Kuala, Banda Aceh dari bulan Juli sampai bulan Agustus 2018. Unit-unit penelitian disusun berdasarkan Rancangan Acak Lengkap (RAL) pola faktorial $4 \times 3$ dengan 3 ulangan dan dilanjutkan dengan uji Beda Nyata Jujur (BNJ) taraf 5\% pada hasil uji $\mathrm{F}$ yang signifikan. Faktor pertama adalah bahan invigorasi dengan 4 jenis bahan yaitu Aquades, PEG, $\mathrm{KNO}_{3}$, dan Air kelapa. Faktor kedua adalah lama perendaman dengan 3 taraf yaitu 12, 24 dan 48 jam. Hasil penelitian menunjukkan bahwa bahan invigorasi terbaik terdapat pada bahan invigorasi menggunakan PEG. Lama perendaman tidak berpengaruh terhadap viabilitas benih padi kadaluarsa. Kombinasi perlakuan terbaik antara bahan invigorasi dan lama perendaman untuk invigorasi benih padi kadaluarsa pada penelitian ini terdapat pada bahan invigorasi menggunakan PEG dan lama perendaman 24 jam.
\end{abstract}

Kata kunci : Bahan invigorasi, padi, viabilitas, vigor

\begin{abstract}
The purpose of this research was to investigate the effect of invigoration technique and soaking duration and interaction between them on the expired rice seed viability. The research was conducted at the Laboratory of Seed Science and Technology Department of Agrotechnology Faculty of Agriculture, Syiah Kuala University, Banda Aceh from July to August 2018. Treatment units were arranged in Factorial Completely Randomized Design (CRD) 4x3 in 3 replications, and the significant data was continued analized by Honestly Significant Different (HSD). The first factor was the invigoration technique that used 4 substance i.e Aquades, PEG, $\mathrm{KNO}_{3}$, and coconut water. While the second factor was duration of soaking i.e 12,24 and 48 hours. The result showed the best concentration for invigoration was one used PEG, while the duration for soaking was not effect on invigoration. The best combination for invigoration of expired rice seeds on this research was PEG and 24 hours of soaking duration.
\end{abstract}

Keyword : Invigorate material, rice, viability, vigor

\section{PENDAHULUAN}

Padi (Oryza sativa L.) merupakan salah satu tanaman serelia yang dikonsumsi lebih dari sebagian besar penduduk di dunia dan menjadi sumber makanan pokok untuk masyarakat Indonesia. Permintaan komoditas ini terus meningkat setiap tahun sehingga membutuhkan penanganan serius sehingga untuk peningkatan penduduk sebesar $2.36 \%$ setiap tahunnya dapat terpenuhi (Prasetiyo, 2006).

Produksi padi di Indonesia meningkat pada tiga tahun terakhir yaitu pada tahun 2015 produksi sebesar 75.398 ton gabah kering giling (GKG) dan terus mengalami peningkatan di tahun 2016 sebesar 79.355 ton GKG hingga pada tahun 2017 meningkat 2,56\% dari tahun 2016 produksi sebesar 81.382 ton GKG. Daerah Aceh berada pada posisi kedua dengan provinsi produksi padi tertinggi setelah Kalimantan Timur untuk persentase pertumbuhan produksi padi tahun 2017 yakni sebesar 20,55\% dari tahun 2016 (Badan Pusat Statistika, 2017). Soejadi et al. (2002) mengemukakan bahwa penurunan tajam daya berkecambah beberapa varietas benih padi terjadi pada periode simpan 16 minggu, sedangkan penurunan tajam vigor benih terjadi padaa periode simpan 12 minggu. Setelah melewati masa penyimpanan peningkatan vigor benih penting menyangkut pengadaan benih, bermanfaat 
dalam bidang pemuliaan maupun konservasi genetik (Ilyas, 1995). Petani pelestari yang membudidayakan padi lokal seperti padi varietas Sigupai menanam dan menyimpan benih sendiri karena tidak tersedianya benih secara komersil (Didi dan Iskandar, 2015). Kondisi ini menyebabkan penyimpanan mutlak di perlukan agar petani dapat menggunakan benih pada musim tanam selanjutnya.

Salah satu metode yang dianggap efektif dalam invigorasi benih yaitu dengan melakukan priming atau conditioning yang terbagi atas osmoconditioning, vitamin priming, hydropriming, organic priming, dan matriconditioning (Erinnovita et al., 2008). Perlakuan osmoconditioning merupakan teknik invigorasi dengan menggunakan bahan larutan osmotik seperti $\mathrm{KNO}_{3}$ dan PEG (polyethylene glycol) untuk mengatur imbibisi air. Berdasarkan hasil penelitian Nurussamawati (2014) Penggunaan PEG -2,0 Bar (- 0,2 MPa) efektif untuk meningkatkan vigor benih padi kadaluarsa varietas Ciherang. Menurut Amstrong dan McDonald (1992), osmoconditioning dengan menggunakan PEG 6000 pada benih kedelai mengurangi kebocoran membran yang berhubungan dengan terkendalinya penyerapan air. Hasil penelitian Farooq et al. (2005) perlakuan osmoconditioning dengan menggunakan larutan $\mathrm{KNO}_{3} 2 \%$ memperlihatkan interaksi nyata dalam peningkatan indeks vigor benih padi hibrida intani-2 pada umur simpan 7 bulan dan 5 bulan. Perlakuan $\mathrm{KNO}_{3}$ juga mampu meningkatkan vigor benih secara nyata pada empat kultivar benih tomat (Farooq et al., 2005).

Air kelapa sebagai sumber ZPT alami mengandung sitokinin, auksin, fosfor, dan giberelin yang berfungsi mempercepat proses pembelahan sel, perkembangan embrio, serta memacu pertumbuhan tunas dan akar (Fatimah, 2008). Penggunaan air kelapa dengan konsentrasi $15 \%$ diinkubasi selama 48 jam pada benih cabai kadaluarsa dapat meningkatkan viabilitas dan vigor benih (Muthiah, 2013). Hasil penelitian Purnawati et al. (2014) menunjukkan baahwa perlakuan osmoconditioning pada benih padi yang diberikan larutan $\mathrm{KNO}_{3} 2 \%$ dan diinkubasi selama 20 jam efektif meningkatkan indeks vigor benih pada periode simpan 3 bulan. Perendaman benih kedelai kadaluarsa menggunakan air kelapa dengan konsentrasi $15 \%$ dan diinkubasi selama 24 jam dapat meningkatkan viabilitas benih (Gunawan, 2004).

Peningkatan vigor maksimum yang diindikasi dari daya berkecambah dan vigor bibit pada perlakuan hydropriming benih padi bermutu baik dan bermutu rendah yaitu 48 jam dan 36 jam. Benih gandum yang diberi perlakuan hydropriming selama 48 jam menunjukkan invigorasi maksimum sebelum benih disemai. (Farooq et al., 2006). Berdasarkan hasil penelitian diatas menunjukkan perlunya dilakukan penelitian untuk mengevaluasi bahan invigorasi yang terbaik untuk benih padi kadaluarsa yang dihubungkan dengan lamanya perendaman.

\section{METODOLOGI PENELITIAN}

\section{Waktu dan Tempat}

Penelitian ini telah dilaksanakan di Laboratorium Ilmu dan Teknologi Benih Jurusan Agroteknologi Fakultas Pertanian Universitas Syiah Kuala, Banda Aceh pada bulan Juli sampai bulan Agustus 2018.

\section{Alat dan Bahan}

\section{Alat}

Alat yang telah digunakan antara lain: autoclave, timbangan digital, gelas ukur 1000 ml, cup plastik sebanyak 36 buah, botol plastik, ayakan, hand sprayer, tray 18 buah, kertas merang, meteran, jangka sorong digital, pinset, kamera, germinator, oven, aerator. 


\section{Bahan}

Bahan yang digunakan pada penelitian ini adalah benih padi varietas Sigupai yang telah disimpan dari tahun 2009 sebanyak 1.080 benih, PEG 6000 sebanyak 561,73 gram, $\mathrm{KNO}_{3}$ sebanyak 90 gram, air kelapa sebanyak 675 ml, aquades sebanyak 18 liter, tanah dan pupuk kandang.

\section{Rancangan Penelitian}

Rancangan Acak Lengkap (RAL) pola factorial digunakan dalam penelitian ini, terdiri dari 2 faktor $4 \times 3$ dengan 3 ulangan. Faktor pertama yaitu bahan invigorasi (T) yang terdiri dari empat jenis bahan yaitu aquades, $\mathrm{PEG}, \mathrm{KNO}_{3}$, dan air kelapa. Faktor kedua yaitu lama perendaman (L) yang terdiri dari tiga taraf yaitu 12 jam, 24 jam dan 48 jam sehingga diperoleh perlakuan dengan 12 kombinasi dan 36 satuan percobaan.

\section{Pelaksanaan Penelitian}

Persiapan Benih

Benih yang telah dipergunakan adalah benih padi varietas Sigupai yang telah disimpan dari tahun 2009 yang diperoleh dari koleksi fakultas pertanian Universitas Syiah Kuala. Setelah dilakukan uji pendahuluan daya berkecambah menjadi $68 \%$. Benih yang akan digunakan direndam dalam air selama 5 menit untuk memisahkan antara yang bernas dengan yang hampa untuk digunakan dalam penelitian.

Pembuatan Larutan Invigorasi

Larutan untuk perlakuan invigorasi dipersiapkan dengan menghitung jumlah kebutuhan aquades, $\mathrm{KNO}_{3}$, PEG 6000 dan air kelapa sesuai dengan konsentrasi dan potensial air larutan yang dicobakan. Untuk bahan kimia PEG 6000 (-2,0 Bar) dibutuhkan 124,83 g/L air, yang diperoleh dengan menggunakan rumus :

$$
\Psi \mathrm{s}=-(1,18 \times 10-2) \mathrm{C}-(1.18 \times 10-4) \mathrm{C}^{2}+(2.67 \times 10-4) \mathrm{CT}+(8.39 \times 10-7) \mathrm{C}^{2} \mathrm{~T}
$$

Keterangan:

$\Psi_{\mathrm{s}} \quad=$ tekanan osmotik larutan (Bar).

$\mathrm{C} \quad=$ konstanta

$\mathrm{T} \quad=$ suhu ruangan dalam ${ }^{\circ} \mathrm{C}$

$1 \mathrm{Bar}=0,1 \mathrm{Mpa}$ (Michael dan Kaufman, 1973).

Untuk larutan $\mathrm{KNO}_{3}$ digunakan konsentrasi $2 \%$ per liter sehingga dibutuhkan 20 gram bahan kimia $\mathrm{KNO}_{3}$ untuk 1 liter air. Sedangkan untuk penggunaan air kelapa digunakan konsentrasi $15 \%$ dalam $500 \mathrm{ml}$ air sehingga dibutuhkan $75 \mathrm{ml}$ air kelapa dalam $500 \mathrm{ml}$ air dengan menggunakan rumus :

$$
15 / 100 \times 500 \mathrm{ml}=75 \mathrm{ml}
$$

Perlakuan Invigorasi Benih

Bahan untuk perlakuan invigorasi yang telah dipersiapkan sesuai dengan konsentrasi dan potensial osmotik dimasukkan dalam wadah botol kaca volume $1000 \mathrm{ml}$. Bahan kimia, dan air kelapa dilarutkan kemudian dibagi kedalam volume $500 \mathrm{ml}$ dan dimasukkan kedalam botol plastik. Kemudian benih dimasukkan sebanyak 30 benih setiap botol. Proses invigorasi disesuaikan dengan lama perendaman dan dimasukkan aerator untuk ketersediaan oksigen. 
Pengecambahan

Benih-benih yang telah direndam dalam bahan invigorasi sesuai perlakuan kemudian dikecambahkan pada substrat kertas merang dengan menggunakan metode Uji Di atas Kertas (UDK) sebanyak 5 lembar yang diberikan air sampai mencapai kapasitas lapang. Kemudian benih-benih tersebut disusun di dalam cup plastik dan diletakkan di dalam germinator selama 14 hari dan dilakukan pengamatan setiap harinya.

Persemaian Benih

Benih yang telah diberi invigorasi kemudian disemai pada tray yang telah diisi tanah top soil dan pupuk kandang yang telah diayak dengan saringan 9 mesh kemudian diberikan air hingga kapasitas lapang. Benih kemudian ditanam tidak terlalu dalam maupun terlalu tinggi dari permukaan tanah. Satu tray dibagi menjadi 2 perlakuan yang terbagi atas 5 benih pada masing-masing perlakuan. Benih yang telah telah ditanam diamati hingga umur 21 HST.

\section{Pemeliharaan}

Pemeliharaan pada bibit tanaman padi yang dilakukan yaitu penyiraman. Penyiraman dilakukan satu kali sehari pada pagi atau sore hari dengan cara penyiraman hingga tanah kapasitas lapang.

\section{Parameter Pengamatan}

Parameter yang diamati adalah parameter viabilitas dan vigor benih padi kadaluarsa yang terdiri dari potensi tumbuh maksimum, daya berkecambah, keserempakan tumbuh, indeks vigor, kecepatan tumbuh relative, berat basah kecambah normal dan berat kering kecambah normal. Parameter pertumbuhan bibit padi terdiri dari tinggi bibit, diameter batang, berat basah bibit dan berat kering bibit.

\section{Analisis Data Penelitian}

Data yang didapat dari hasil penelitian dianalisis menggunakan ANOVA. Apabila hasil dari ujii $\mathrm{F}$ yang menunjukkan berpengaruh nyata $(\alpha=5 \%)$, diuji lanjut dengan menggunakan prosedur uji lanjut Uji Beda Nyata Jujur (BNJ) pada taraf $5 \%$.

\section{HASIL DAN PEMBAHASAN}

Berdasarkan hasil penelitian yang disajikan analisis ragam (Uji F) untuk invigorasi benih padi kadaluarsa terhadap beberapa bahan invigorasi dan lama perendaman yang berbeda serta interaksi antara kedua faktor pada berbagai tolok ukur viabilitas dan vigor benih padi kadaluarsa dapat dilihat pada Tabel 1.

Tabel 1 memperlihatkan baahwa perlakuan bahan invigorasi berpengaruh sangat nyata terhadap tolok ukur ukur potensi tumbuh maksimum, daya berkecambah, keserempakan tumbuh, kecepatan tumbuh relatif, berat basah kecambah normal, dan berat kering kecambah normal, namun tidak berpengaruh nyata pada indeks vigor. Pada perlakuan lama perendaman berpengaruh nyata terhadap tolok ukur berat basah kecambah normal, namun tidak berpengaruh nyata terhadap tolok ukur lainnya. Interaksi antara perlakuan bahan invigorasi dan lama perendaman sangat nyata pada tolok potensi tumbuh maksimum dan berpengaruh nyata pada indeks vigor, berat kering kecambah normal, dan berat basah kecambah normal, namun tidak nyata pada tolok daya berkecambah, keserempakan tumbuh dan kecepatan tumbuh relatif. 
Tabel 1. Rekapitulasi Hasil Analisis Ragam (Uji F) Invigorasi Benih Padi (Oryza sativa L.) Kadaluarsa dengan Beberapa Bahan Invigorasi dan Lama Perendaman yang Berbeda terhadap Tolok Ukur Viabilitas dan Vigor Benih Padi Kadaluarsa

\begin{tabular}{cccccccc}
\hline \multirow{2}{*}{ Perlakuan } & \multicolumn{7}{c}{ Tolok Ukur Viabilitas dan Vigor Benih } \\
\cline { 2 - 8 } & PTM & DB & $\mathrm{K}_{\mathrm{ST}}$ & IV & $\mathrm{K}_{\mathrm{CT}}-\mathrm{R}$ & $\mathrm{BKKN}$ & BBKN \\
\hline $\mathrm{T}$ & $* *$ & $* *$ & $* *$ & tn & $* *$ & $* *$ & $* *$ \\
$\mathrm{~L}$ & tn & tn & tn & tn & tn & tn & $*$ \\
TxL & $* *$ & tn & tn & $*$ & tn & $*$ & $*$ \\
\hline KK $(\%)$ & 6,06 & 25,63 & 26,52 & 34,46 & 18,03 & 49,10 & 16,33
\end{tabular}

Keterangan : Pada Uji BNJ taraf 0,05*: Berpengaruh nyata, **: Berpengaruh sangat nyata, tn: Tidak berpengaruh nyata; T: Bahan Invigorasi, L: Lama perendaman, TxL: Interaksi antara Bahan Invigorasi dan Lama perendaman, KK: Koefisien keragaman, PT: Potensi tumbuh maksimum, DB: Daya berkecambah, $\mathrm{K}_{\mathrm{ST}}$ : Keserempakan tumbuh, IV: Indeks vigor, $\mathrm{K}_{\mathrm{CT}^{-}}$ R: Kecepatan tumbuh relative, BBKN: Berat basah kecambah normal dan BKKN: Berat kering kecambah normal

\section{Pengaruh Bahan Invigorasi terhadap Viabilitas dan Vigor Benih Padi Kadaluarsa.}

Berdasarkan hasil penelitian yang disajikan dalam analisis ragam (Uji $F$ ) pada menunjukkan bahwaa pada perlakuan bahan invigorasi berpengaruh sangat nyata terhadap parameter untuk potensi tumbuh maksimum, daya berkecambah, keserempakan tumbuh dan kecepatan tumbuh relatif, berat kering kecambah normal, dan berat kering kecambah normal, namun tidak berpengaruh nyata pada tolok ukur indeks vigor.

Nilai rata-rata untuk beberapa parameter viabilitas dan vigor benih pada berbagai bahan invigorasi disajikan pada Tabel 2.

Tabel 2. Rata-rata Nilai Viabilitas dan Vigor Benih Padi (Oryza sativa L.) Kadaluarsa pada Beberapa Bahan Invigorasi.

\begin{tabular}{|c|c|c|c|c|c|c|c|}
\hline \multirow[b]{2}{*}{$\begin{array}{c}\text { Bahan } \\
\text { Invigorasi }\end{array}$} & \multicolumn{7}{|c|}{ Tolok ukur viabilitas dan vigor benih } \\
\hline & $\begin{array}{c}\text { PTM } \\
(\%)\end{array}$ & $\begin{array}{l}\text { DB } \\
(\%)\end{array}$ & $\begin{array}{l}\mathrm{KST} \\
(\%)\end{array}$ & $\begin{array}{l}\text { IV } \\
(\%)\end{array}$ & $\begin{array}{c}\text { KCT-R } \\
(\%)\end{array}$ & $\begin{array}{c}\text { BKKN } \\
(\mathrm{mg})\end{array}$ & $\begin{array}{c}\text { BBKN } \\
(\mathrm{mg})\end{array}$ \\
\hline Aquades & $80,4 \mathrm{a}$ & $47,11 \mathrm{a}$ & $34,67 \mathrm{a}$ & $\begin{array}{c}14,67 \\
(20,49)\end{array}$ & $39,03 \mathrm{a}$ & $17,78 \mathrm{~b}$ & $77,65 \mathrm{a}$ \\
\hline PEG & $92 \mathrm{c}$ & $70,22 \mathrm{~b}$ & $55,11 \mathrm{~b}$ & $\begin{array}{c}21,33 \\
(26,73)\end{array}$ & $58,53 \mathrm{c}$ & $\begin{array}{c}16,94 \\
\mathrm{ab}\end{array}$ & $85,98 \mathrm{ab}$ \\
\hline $\mathrm{KNO}_{3}$ & $85,8 \mathrm{~b}$ & $63,56 \mathrm{ab}$ & $45,78 \mathrm{ab}$ & $\begin{array}{c}17,33 \\
(24,13)\end{array}$ & $54,27 \mathrm{bc}$ & $20 \mathrm{~b}$ & $100,70 \mathrm{~b}$ \\
\hline Air Kelapa & $\begin{array}{c}81,8 \\
a b\end{array}$ & $61,78 \mathrm{ab}$ & 39,11 a & $\begin{array}{c}12,00 \\
(19,55)\end{array}$ & $43,86 \mathrm{ab}$ & $13,42 \mathrm{a}$ & $72,54 \mathrm{a}$ \\
\hline BNJ 0,05 & 5,30 & 17,08 & 14,19 & - & 13,80 & 3,93 & 17,86 \\
\hline
\end{tabular}

Keterangan : -Angka yang diikuti oleh huruf yang sama pada kolom yang sama berbeda tidak nyata pada taraf 0,05 (Uji BNJ)

-() Angka transformasi ArcSin $\sqrt{p}$

Pengaruh Bahan Invigorasi dan Lama Perendaman Pada Benih Padi (Oryza sativa L.) Kadaluarsa Terhadap 
Tabel 2 memperlihatkan bahwasanya parameter PTM tertinggi terdapat pada bahan invigorasi dengan menggunakan PEG hal ini juga terlihat pada DB, KST, dan KCT-R. Pada potensi tumbuh maksimum, bahan invigorasi dengan menggunakan aquades berbeda nyata dengan pemberian PEG dan KNO3 namun berbeda tidak nyata dengan pemberian air kelapa, sedangkan pemberian air kelapa juga berbeda tidak nyata dengan KNO3. Pada daya berkecambah bahan invigorasi dengan air aquades berbeda nyata dengan PEG namun berbeda tidak nyata dengan KNO3 dan air kelapa. Pada keserempakan tumbuh bahan invigorasi dengan aquades berbeda nyata dengan PEG namun tidak berbeda nyata dengan KNO3 dan air kelapa. Pada kecepatan tumbuh relatif bahan invigorasi dengan aquades berbeda nyata dengan PEG dan KNO3 namun tidak berbeda nyata dengan air kelapa. Pada berat kering kecambah normal tertinggi terdapat pada bahan invigorasi dengan KNO3 yang berbeda nyata dengan air kelapa namun tidak berbeda nyata dengan aquades dan PEG. Pada berat basah kecambah normal tertinggi terdapat pada bahan invigorasi dengan $\mathrm{KNO} 3$ yang terlihat berbeda dengan aquades dan air kelapa namun tidak berbeda nyata dengan PEG.

\section{Pengaruh Lama Perendaman Terhadap Viabilitas dan Vigor Benih Padi Kadaluarsa.}

Hasil analisis ragam (Uji F) menunjukkan bahwa lama perendaman berpengaruh nyata terhadap tolok ukur berat basah kecambah normal, namun tidak berpengaruh pada PTM, DB, KST, indeks vigor dan KCT-R, dan BBKN.

Tabel 3 menunjukkan bahwa berat basah kecambah normal tertinggi terdapat pada lama perendaman 24 jam yang berbeda nyata dengan lama perendaman 12 jam dan tidak berbeda nyata dengan perendaman 48 jam.

Rata-rata nilai potensi tumbuh maksimum, daya berkecambah, keserempakan tumbuh, indeks vigor, kecepatan tumbuh relatif dan berat kering kecambah normal pada lama perendaman yang berbeda dapat dilihat pada Tabel 3 .

Tabel 3. Rata-rata Nilai Viabilitas dan Vigor Benih Padi (Oryza sativa L.) Kadaluarsa dengan Lama Perendaman yang Berbeda

\begin{tabular}{cccccccc}
\hline $\begin{array}{c}\text { Lama } \\
\text { Perendaman }\end{array}$ & \multicolumn{7}{c}{ Tolok ukur viabilitas dan vigor benih } \\
\cline { 2 - 8 } & $\begin{array}{c}\text { PTM } \\
(\%)\end{array}$ & $\begin{array}{c}\text { DB } \\
(\%)\end{array}$ & $\begin{array}{c}\text { KST } \\
(\%)\end{array}$ & $\begin{array}{c}\text { IV } \\
(\%)\end{array}$ & $\begin{array}{c}\text { KCT-R } \\
(\%)\end{array}$ & $\begin{array}{c}\text { BKKN } \\
(\mathrm{mg})\end{array}$ & $\begin{array}{c}\text { BBKN } \\
(\mathrm{mg})\end{array}$ \\
\hline \multirow{2}{*}{12 jam } & 84,33 & 61,00 & 43,67 & $\begin{array}{c}17,00 \\
(23,72)\end{array}$ & 51,12 & 16,81 & $75,08 \mathrm{a}$ \\
\multirow{2}{*}{24 jam } & 85,00 & 63,33 & 49,33 & $\begin{array}{c}19,33 \\
(25,53) \\
12,67\end{array}$ & 52,90 & 16,60 & $93,66 \mathrm{~b}$ \\
48 jam & 85,67 & 57,67 & 38,00 & $\begin{array}{c}1 \\
(18,92)\end{array}$ & 42,75 & 17,71 & $83,92 \mathrm{ab}$ \\
\hline BNJ 0,05 & - & - & - & - & - & - & 13,97 \\
\hline
\end{tabular}

Keterangan :-Angka yang diikuti oleh huruf yang sama pada kolom yang sama berbeda tidak nyata pada Taraf 0,05 (Uji BNJ)

-() Angka transformasi ArcSin $\sqrt{p}$ 


\section{Interaksi antara Bahan Invigorasi dan Lama Perendaman Terhadap Potensi Tumbuh Maksimum (\%) Benih Padi Kadaluarsa.}

Hasil analisis ragam (Uji F) menunjukkan adanya interaksi yang sangat nyata antara perlakuan bahan invigorasi dan pengaruh lama perendaman terhadap tolok ukur potensi tumbuh maksimum. Nilai potensi tumbuh maksimum benih padi kadaluarsa akibat interaksi antara perlakuan bahan invigorasi dan pengaruh lama perendaman dapat dilihat pada Tabel 4 .

Tabel 4. Rata-rata Nilai interaksi antara Beberapa Bahan Invigorasi dan Lama Perendaman yang Berbeda terhadap Potensi Tumbuh Maksimum

\begin{tabular}{cccc}
\hline \multirow{2}{*}{ Bahan Invigorasi } & \multicolumn{3}{c}{ Lama perendaman } \\
\cline { 2 - 4 } & 12 jam $\left(\mathrm{L}_{1}\right)$ & 24 jam $\left(\mathrm{L}_{2}\right)$ & 48 jam $\left(\mathrm{L}_{3}\right)$ \\
\hline Aquades $\left(\mathrm{T}_{0}\right)$ & $80,00 \mathrm{abc}$ & $82,67 \mathrm{abcd}$ & $78,67 \mathrm{ab}$ \\
PEG $\left(\mathrm{T}_{1}\right)$ & $92,00 \mathrm{~cd}$ & $90,67 \mathrm{bcd}$ & $93,33 \mathrm{~d}$ \\
$\mathrm{KNO}_{3}\left(\mathrm{~T}_{2}\right)$ & $80,00 \mathrm{abc}$ & $92,00 \mathrm{~cd}$ & $85,33 \mathrm{abcd}$ \\
Air Kelapa $\left(\mathrm{T}_{3}\right)$ & $85,33 \mathrm{abcd}$ & $74,67 \mathrm{a}$ & $85,33 \mathrm{abcd}$ \\
\hline BNJ & & 12,08
\end{tabular}

Keterangan : Angka yang diikuti oleh huruf yang sama berbeda tidak nyata pada taraf 0,05 (Uji BNJ).

Tabel 4 menunjukkan bahwa kombinasi perlakuan antara beberapa bahan invigorasi dan lama perendaman terhadap tolok ukur potensi tumbuh maksimum tertinggi terdapat pada perlakuan bahan invigorasi menggunakan PEG dengan lama perendaman 48 jam (T1L3) yang berbeda nyata dengan bahan invigorasi menggunakan aquades dengan lama perendaman 48 jam (TOL3). Pada perendaman 24 jam bahan invigoras dengan menggunakan PEG dan KNO3 berbeda nyata dengan bahan invigorasi menggunakan air kelapa, sedangkan aquades tidak berbeda nyata dengan bahan invigorasi air kelapa.

\section{Interaksi antara Bahan Invigorasi dan Lama Perendaman Terhadap Indeks Vigor Benih Padi Kadaluarsa.}

Berdasarkan dari hasil penelitian yang disajikan dalam analisis ragam (Uji F) menunjukkan interaksi yang nyata pada perlakuan bahan invigorasi dan pengaruh lama perendaman terhadap tolok ukur indeks vigor. Nilai indeks vigor benih padi kadaluarsa akibat interaksi antara perlakuan bahan invigorasi dan pengaruh perendaman lama dapat dilihat padaTabel 5.

Tabel 5. Nilai interaksi antara Beberapa Bahan Invigorasi dan Lama Perendaman yang Berbeda terhadap Indeks Vigor

\begin{tabular}{cccc}
\hline \multirow{2}{*}{ Bahan Invigorasi } & \multicolumn{3}{c}{ Lama perendaman } \\
\cline { 2 - 4 } & 12 jam $\left(\mathrm{L}_{1}\right)$ & 24 jam $\left(\mathrm{L}_{2}\right)$ & 48 jam $\left(\mathrm{L}_{3}\right)$ \\
\hline Aquades $\left(\mathrm{T}_{0}\right)$ & $24,57 \mathrm{ab}$ & $29,00 \mathrm{~b}$ & $7,88 \mathrm{a}$ \\
PEG $\left(\mathrm{T}_{1}\right)$ & $30,12 \mathrm{~b}$ & $29,28 \mathrm{~b}$ & $20,18 \mathrm{ab}$ \\
$\mathrm{KNO}_{3}\left(\mathrm{~T}_{2}\right)$ & $24,11 \mathrm{ab}$ & $25,39 \mathrm{ab}$ & $22,88 \mathrm{ab}$ \\
Air Kelapa $\left(\mathrm{T}_{3}\right)$ & $16,08 \mathrm{ab}$ & $18,46 \mathrm{ab}$ & $24,11 \mathrm{ab}$ \\
\hline BNJ & \multicolumn{4}{c}{18,92} \\
\hline
\end{tabular}


Keterangan : Angka yang diikuti oleh huruf yang sama berbeda tidak nyata pada taraf 0,05 (Uji BNJ).

Tabel 5 menunjukkan bahwa kombinasi perlakuan antara beberapa bahan invigorasi dan lama perendaman terhadap tolok ukur indeks vigor tertinggi terdapat pada perlakuan bahan invigorasi menggunakan PEG dengan lama perendaman 12 jam $\left(\mathrm{T}_{1} \mathrm{~L}_{1}\right)$ yang berbeda nyata dengan bahan invigorasi aquades 48 jam $\left(\mathrm{T}_{0} \mathrm{~L}_{3}\right)$.

Hasil penelitian menunjukkan bahwa lama perendaman tidak menyebabkan perubahan yang nyata pada bahan invigorasi menggunakan PEG, KNO3 maupun air kelapa namun pada bahan invigorasi dengan aquades terdapat pengaruh yang nyata antara perendaman 24 jam dan 48 jam dimana terjadinya penurunan secara drastis antara perendaman 24 jam dengan 48 jam.

\section{Interaksi antara Bahan Invigorasi dan Lama Perendaman terhadap Berat Kering Kecambah Normal (mg) Benih Padi Kadaluarsa.}

Berdasarkan hasil penelitian yang disajikan dalam analisis ragam (Uji F) menunjukkan interaksi nyata pada perlakuaan bahan invigorasi dan pengaruh lama perendaman terhadap tolok ukur berat kering kecambah normal. Nilai berat kering kecambah normal benih padi kadaluarsa akibat interaksi antara perlakuan bahan invigorasi dan pengaruh lama perendaman dapat dilihat pada Tabel 6.

Tabel 6. Nilai interaksi antara Beberapa Bahan Invigorasi dan Lama Perendaman yang Berbeda terhadap Berat Kering Kecambah Normal

\begin{tabular}{cccc}
\hline \multirow{2}{*}{ Teknik Invigorasi } & \multicolumn{3}{c}{ Lama perendaman } \\
\cline { 2 - 4 } & 12 jam $\left(\mathrm{L}_{1}\right)$ & 24 jam $\left(\mathrm{L}_{2}\right)$ & 48 jam $\left(\mathrm{L}_{3}\right)$ \\
\hline Aquades $\left(\mathrm{T}_{0}\right)$ & $14,41 \mathrm{ab}$ & $19,39 \mathrm{~b}$ & $19,54 \mathrm{~b}$ \\
PEG $\left(\mathrm{T}_{1}\right)$ & $14,69 \mathrm{ab}$ & $18,99 \mathrm{~b}$ & $17,15 \mathrm{ab}$ \\
$\mathrm{KNO}_{3}\left(\mathrm{~T}_{2}\right)$ & $20,47 \mathrm{~b}$ & $18,84 \mathrm{~b}$ & $20,70 \mathrm{~b}$ \\
Air Kelapa $\left(\mathrm{T}_{3}\right)$ & $17,65 \mathrm{ab}$ & $9,18 \mathrm{a}$ & $13,44 \mathrm{ab}$ \\
\hline BNJ & & 8,92 \\
\hline
\end{tabular}

Keterangan : Angka yang diikuti oleh huruf yang sama berbeda tidak nyata pada taraf 0,05 (Uji BNJ).

Tabel 6 menunjukkan bahwa kombinasi perlakuan antara beberapa bahan invigorasi dan lama perendaman terhadap tolok ukur berat kering kecambah normal tertinggi terdapat pada perlakuan bahan invigorasi menggunakan $\mathrm{KNO}_{3}$ dengan lama perendaman 48 jam $\left(\mathrm{T}_{2} \mathrm{~L}_{3}\right)$ yang hanya berbeda nyata dengan bahan invigorasi menggunakan air kelapa dengan lama perendaman 24 jam $\left(\mathrm{T}_{3} \mathrm{~L}_{2}\right)$.

Hasil penelitian menunjukkan bahwa lama perendaman tidak menyebabkan perubahan yang nyata pada bahan invigorasi menggunakan aquades, PEG dan KNO3 namun pada bahan invigorasi air kelapa terjadi penurunan pada lama perendaman 24 jam jika dibandingkan lainnya. 


\section{Interaksi antara Bahan Invigorasi dan Lama Perendaman terhadap Berat Basah Kecambah Normal (mg) Benih Padi Kadaluarsa.}

Berdasarkan hasil penelitian yang disajikan dalam analisis ragam (Uji F) menunjukkan interaksi nyata pada perlakuan bahan invigorasi dan pengaruh lama perendaman terhadap tolok ukur berat basah kecambah normal. Nilai berat basah kecambah normal benih padi kadaluarsa akibat interaksi antara perlakuan bahan invigorasi dan pengaruh lama perendaman disajikandalam Tabel 7.

Tabel 7 memperlihatkan bahwasanya kombinasi pada beberapa bahan invigorasi dan lama perendaman pada tolok ukur berat basah kecambah normal tertinggi terdapat pada perlakuan bahan invigorasi menggunakan KNO3 dengan lama perendaman 48 jam (T2L3) yang berbeda nyata dengan bahan invigorasi menggunakan aquades dan air kelapa pada perendaman 48 jam.

Tabel 7. Nilai interaksi antara Beberapa Bahan Invigorasi dan Lama Perendaman yang Berbeda terhadap Berat Basah Kecambah Normal

\begin{tabular}{cccc}
\hline \multirow{2}{*}{ Teknik Invigorasi } & \multicolumn{3}{c}{ Lama perendaman } \\
\cline { 2 - 4 } & 12 jam $\left(\mathrm{L}_{1}\right)$ & 24 jam $\left(\mathrm{L}_{2}\right)$ & 48 jam $\left(\mathrm{L}_{3}\right)$ \\
\hline Aquades $\left(\mathrm{T}_{0}\right)$ & $62,48 \mathrm{a}$ & $97,95 \mathrm{ab}$ & $72,53 \mathrm{a}$ \\
PEG $\left(\mathrm{T}_{1}\right)$ & $70,75 \mathrm{a}$ & $102,10 \mathrm{ab}$ & $85,09 \mathrm{ab}$ \\
$\mathrm{KNO}_{3}\left(\mathrm{~T}_{2}\right)$ & $85,35 \mathrm{ab}$ & $102,69 \mathrm{ab}$ & $114,06 \mathrm{~b}$ \\
Air Kelapa $\left(\mathrm{T}_{3}\right)$ & $81,75 \mathrm{ab}$ & $71,90 \mathrm{a}$ & $63,98 \mathrm{a}$ \\
\hline BNJ & & 40,44 &
\end{tabular}

Keterangan : Angka yang diikuti oleh huruf yang sama berbeda tidak nyata pada taraf 0,05 (Uji BNJ).

Hasil penelitian menunjukkan bahwa lama perendaman tidak menyebabkan perubahan yang nyata pada bahan invigorasi menggunakan aquades, PEG, KNO3 maupun air kelapa terhadap tolok ukur berat basah kecambah normal.

Rekapitulasi Hasil Analisis Ragam (Uji F) Invigorasi Benih Padi (Oryza sativa L.) Kadaluarsa dengan Beberapa Bahan Invigorasi dan Lama Perendaman yang Berbeda terhadap Pertumbuhan Bibit Padi Kadaluarsa

Berdasarkan hasil penelitian yang disajikan dalam analisis ragam (Uji F) invigorasi untuk benih padi kadaluarsa menggunakan beberapa bahan invigorasi merah dan lama perendaman yang berbeda dan interaksi kedua faktor terhadap pertumbuhan bibit padi kadaluarsa disajikan pada Tabel 8 .

Tabel 8 memperlihatkan bahwasanya pada perlakuan bahan invigorasi dan lama perendaaman tidak menunjukkan berpengaruh nyata terhadap semua tolok ukur pertumbuhan bibit yaitu tinggi tanaman, diameter bibit, berat basah bibit, dan berat kering bibit. Interaksi antara perlakuan bahan invigorasi dan lama perendaman berpengaruh nyata pada berat kering bibit namun tidak berpengaruh nyata pada tolok ukur pertumbuhan bibit lainnya yakni tinggi tanaman, diameter bibit, berat basah bibit, berat kering. 
Tabel 8. Rekapitulasi Hasil Analisis Ragam (Uji F) Invigorasi Benih Padi (Oryza sativa L.) Kadaluarsa dengan Beberapa Bahan Invigorasi dan Lama Perendaman yang Berbeda terhadap Pertumbuhan Bibit

\begin{tabular}{|c|c|c|c|c|}
\hline \multirow[b]{2}{*}{ Perlakuan } & \multicolumn{4}{|c|}{ Tolok Pertumbuhan Bibit } \\
\hline & $\begin{array}{c}\text { Tinggi } \\
\text { Tanaman }\end{array}$ & $\begin{array}{c}\text { Diameter } \\
\text { Bibit }\end{array}$ & Berat Basah Bibit & Berat Kering Bibit \\
\hline $\mathrm{T}$ & tn & tn & tn & tn \\
\hline $\mathrm{L}$ & tn & tn & tn & tn \\
\hline TxL & $\operatorname{tn}$ & tn & tn & $*$ \\
\hline $\mathrm{KK}(\%)$ & 26,78 & 29,53 & 33,45 & 121,67 \\
\hline
\end{tabular}

Keterangan :*: Berpengaruh Nyata; **: Berpengaruh sangat nyata; Tn: Tidak berpengaruh nyata; : Bahan Invigorasi; L: Lama perendaman (Jam); TxL: Interaksi antara Bahan invigorasi dan Lama perendaman; KK: Koefisien keragaman (\%).

\section{Interaksi antara Bahan Invigorasi dan Lama Perendaman terhadap Berat Kering Bibit Padi Kadaluarsa}

Berdasrkan hasil penelitian yang disajikan dalam analisis ragam (Uji F) memperlihatkan bahwasanya interaksi yang nyata pada perlakuan bahan invigorasi dan pengaruh lama perendaman terhadap tolok ukur berat kering bibit. Nilai berat kering bibit padi kadaluarsa akibat interaksi antara perlakuan bahan invigorasi dan pengaruh lama perendamaan disajikan dalam Tabel 9.

Tabel 9. Nilai interaksi antara Beberapa Bahan Invigorasi dan Lama Perendaman yang Berbeda terhadap Berat Kering Bibit

\begin{tabular}{cccc}
\hline Teknik & \multicolumn{3}{c}{ Lama Perendaman } \\
\cline { 2 - 4 } Invigorasi & 12 Jam $\left(\mathrm{L}_{1}\right)$ & 24 Jam $\left(\mathrm{L}_{2}\right)$ & 48 Jam $\left(\mathrm{L}_{3}\right)$ \\
\hline Aquades $\left(\mathrm{T}_{0}\right)$ & $0,12 \mathrm{a}$ & $0,16 \mathrm{a}$ & $0,63 \mathrm{a}$ \\
$\mathrm{PEG}\left(\mathrm{T}_{1}\right)$ & $0,15 \mathrm{a}$ & $0,22 \mathrm{a}$ & $0,15 \mathrm{a}$ \\
$\mathrm{KNO}_{3}\left(\mathrm{~T}_{2}\right)$ & $0,16 \mathrm{a}$ & $0,19 \mathrm{a}$ & $0,19 \mathrm{a}$ \\
Air kelapa $\left(\mathrm{T}_{3}\right)$ & $0,14 \mathrm{a}$ & $0,13 \mathrm{a}$ &
\end{tabular}

Keterangan :-Angka yang diikuti oleh huruf yang sama pada kolom yang sama berbeda tidak nyata pada taraf 0,05 (Uji BNJ)

Tabel 9 memperlihatkan bahwasanya untuk kombinasi pada beberapa bahan invigorasi dan lama perendaman untuk berat kering bibit tidak menunjukkan adanya pengaruh nyata antar perlakuan namun berdasarkan tabel dapat dilihat bahwa nilai berat kering bibit tertinggi terdapat pada perlakuan PEG dengan lama perendaman 24 jam (T1L3) walaupun tidak terlihat perbedaan nyata secara statistik.

\section{Pembahasan}

\section{Pengaruh Bahan Invigorasi}

Hasil penelitian yang telah dilakukan menunjukkan bahwa perlakuan bahan invigorasi memberikan pengaruh yang sangat nyata pada beberapa tolok ukur viabilitas dan vigor benih 
yakni PTM, DB, KST, KCT-R, berat basah kecambah normal dan berat kering kecambah normal namun tidak menunjukkan pengaruh pada daya berkecambah dan indeks vigor. Secara keseluruhan, bahan invigorasi yang memberikan pengaruh yang sangat baik terhadap viabilitas dan vigor benih padi kadaluarsa yaitu PEG 6000 -2.0 Bar. Hal ini sejalan dengan hasil penelitian Nurussamawati (2014) bahwa larutan PEG 6000 -2.0 Bar efektif dalam peningkatan nilai PTM pada padi ciherang kadaluarsa. PEG memiliki sifat mempertahankan potensial air media imbibisi sehingga pada saat terjadinya proses imbibisi memungkinkan benih mengoptimalkan faktor internalnya untuk memulai proses perkecambahan seperti pemulihan integritas membran karena benih yang mengalami deteriorasi terjadi perubahan permeabilitas membran yang menyebabkan kerusakan dinding sel sehingga terjadi kebocoran sel jika benih berimbibisi (Ruliansyah, 2011). PEG juga dapat membentuk lapisan yang membatasi jumlah air yang diabsorbsi oleh benih atau hidrasi sebagian sehingga molekul PEG yang berada di luar membran sel benih akan membentuk lapisan tipis yang melindungi benih dan berfungsi sebagai penyangga kadar air benih dan keluar masuknya oksigen (Rahardjo, 1986).

Sedangkan $\mathrm{KNO}_{3}$ diketahui berfungsi untuk meningkatkan aktifitas hormon pada benih. Namun pada penelitian ini pengaruh $\mathrm{KNO}_{3}$ kurang efektif jika dibandingkan dengan perbedaan nilai antara PEG dan $\mathrm{KNO}_{3}$. Konsentrasi $\mathrm{KNO}_{3}$ yang kurang efektif menyebabkan $\mathrm{KNO}_{3}$ tidak dapat mensuplai nitrogen dan nutrisi esensial bagi protein pada saat perkecambahan benih (Copeland dan McDonald, 2001). Setelah diuji lanjut bahan invigorasi $\mathrm{KNO}_{3}$ dan PEG tidak menunjukkan adanya perbedaan yang nyata namun nilai $\mathrm{KNO}_{3}$ dan PEG lebih tinggi secara statistik dibandingkan dengan bahan invigorasi dengan menggunakan aquades dan air kelapa. Air kelapa memiliki hormon alami yang dapat merangsang pertumbuhan tanaman (Afriza, 2010), namun pada bahan invigorasi dengan air kelapa tidak efektif karena benih tidak mampu menyerap hormon pada saat terjadinya proses imbibisi dikarenakan benih telah mengalami kebocoran sel. Bahan invigorasi dengan aquades pada benih padi kadaluarsa juga tidak efektif karena menyebabkan imbibisi tidak terkendali oleh membran sel sehingga mengganggu aktivitas metabolisme benih dan mengganggu perkecambahan. Menurut Zanzibar (2007) prinsip utama dari priming yaitu untuk memaksimalkan pertumbuhan kecambah dengan cara mengatur laju penyerapan air oleh embrio.

Pada tolok ukur berat basah bibit dan berat kering bibit, nilai tertinggi terdapat pada bahan invigorasi dengan $\mathrm{KNO}_{3}$. Robert dan Smith (1977) $\mathrm{KNO}_{3}$ terurai menjadi $\left(\mathrm{NO}_{3}^{-}\right)$dan $\left(\mathrm{K}^{+}\right)$pada saat terjadinya imbibisi air yang kemudian secara bersamaan ion nitrat meresap dan masuk kedalam benih menyebabkan aktifitas hormon yang tinggi dan memicu proses metabolisme benih. Sedangkan PEG bersifat menahan air masuk kedalam benih sehingga tidak tersedia bagi tanaman dan menghambat proses perombakan cadangan makanan dan metabolisme benih (Michael dan Kaufman, 1973), hal ini dibuktikan dengan rendahnya berat basah kecambah normal dan berat kering kecambah normal. Sedangkan pada air kelapa terdapat beberapa mineral seperti kalium, natrium, kalsium dan lainnya (Maemunah et al., 2009) yang mungkin tidak dapat terserap oleh benih yang diinvigorasi sehingga sisa cadangan makanan yang terdapat didalam benih tidak dapat terpakai. Menurut Nurussintani et al. (2012) menyatakan bahwa benih dengan vigor tinggi dapat membentuk dan mentranslokasikan bahan baku ke poros embrio dengan cepat sehingga meningkatkan akumulasi berat kering. Berat kering yang tinggi dapat menggambarkan pemanfaatan cadangan makanan dalam benih yang efisien. 


\section{Pengaruh Lama Perendaman}

Berdasarkan Tabel 3 lama perendaman tidak menunjukkan adanya pengaruh pada hampir semua tolok ukur viabilitas dan vigor benih kecuali berat basah kecambah normal. Perendaman dengan jangka waktu 12 jam, 24 jam dan 48 jam dinilai tidak efektif karena diduga benih telah mengalami kebocoran pada saat terjadinya proses imbibisi. Rusaknya membran sel juga sebagai penyebab benih tidak dapat memanfaatkan air secara optimal. Perendaman yang tepat dapat mempercepat reaksi metabolisme dan memberikan pengaruh terhadap aktivitas enzim sehingga terjadilah pembelahan sel (Evi susanti, 2014). Menurut Utomo (2006) perendaman yang terlalu lama menyebabkan terjadinya anoksia (kehilangan oksigen) sehingga membatasi proses respirasi dan menghambat perkecambahan. Pada berat basah kecambah normal terlihat adanya pengaruh nyata pada perendaman 12 jam dan 24 jam. Hal ini dikarenakan pada 12 jam perendaman benih belum memaksimalkan air yang masuk sedangkan pada 24 jam perendaman benih telah mengoptimalkan jumlah air yang masuk kedalam benih. Namun pada perendaman 48 jam terlihat bahwa tidak menunjukkan adanya pengaruh nyata dengan perendaman 24 jam secara statistik tapi nilai yang dihasilkan menurun daripada perendaman 24 jam diduga benih telah kehilangan oksigen sehingga menghambat perkecambahan. Menurut Evi (2014) setelah diberikan perlakuan, terjadinya pemasukan air secara perlahan. Air yang masuk dapat mengorganisir membran sel, mengaktifkan enzim dan organel lainnya terutama mitokondria.

\section{Pengaruh Interaksi Bahan Invigorasi dan Lama Perendaman}

Berdasarkan hasil penelitian kombinasi perlakuan antara bahan invigorasi dan lama perendaman berpengaruh pada 4 tolok ukur yaitu potensi tumbuh maksimum, indeks vigor, berat basah kecambah normal, berat kering kecambah normal dan satu pada tolok ukur pertumbuhan bibit yaitu berat kering bibit. Bahan invigorasi dengan menggunakan PEG menunjukkan nilai tertinggi pada interaksi tolok ukur potensi tumbuh, indeks vigor dan berat kering bibit sedangkan pada tolok ukur berat basah kecambah normal dan berat kering kecambah normal nilai tertinggi yaitu pada invigorasi menggunakan $\mathrm{KNO}_{3}$. Namun secara keseluruhan pengaruh dari bahan invigorasi PEG dan KNO3 yang berinteraksi dengan semua lama perendaman hampir tidak menunjukkan adanya pengaruh jika dilihat dari hasil uji lanjut menggunakan BNJ taraf nyata 5\%. Perlakuan bahan invigorasi dengan menggunakan PEG relatif lebih tinggi daripada perlakuan bahan invigorasi lain. Hal ini membuktikan bahwa PEG mampu menahan kebocoran benih padi kadaluarsa dengan cara menahan air dan membentuk lapisan tipis yang dapat mengurangi terjadi kebocoran benih pada saat imbibisi. Menurut Rahardjo (1986) lapisan tipis yang dibentuk oleh larutan PEG 6000 berfungsi untuk menahan kadar air dan keluar masuknya oksigen sehingga dapat melindungi benih. Namun pada bahan invigorasi PEG tidak terlihat adanya pengaruh nyata dengan lama perendaman. Pada perlakuan bahan invigorasi Hal ini menunjukkan bahwa lama perendaman tidak berpengaruh secara nyata pada bahan invigorasi PEG.

Bahan invigorasi PEG dengan lama perendaman 48 jam menunjukkan nilai tertinggi pada tolok ukur potensi tumbuh maksimum yaitu 93,33\% yang berbeda nyata dengan $\mathrm{KNO}_{3}$ dengan lama perendaman 12 jam yaitu 80\%. Menurut Yari et al. (2012) perlakuan osmopriming pada benih padi dengan menggunakan PEG mampu mempercepat waktu ratarata perkecambahan dibanding dengan benih tanpa perlakuan. Hasil penelitian ini menunjukkan bahwa pada perlakuan bahan invigorasi dengan perendaman yang tepat dapat mengaktifkan metabolisme dan mempercepat perkecambahan. Pada tolok ukur indeks vigor, bahan invigorasi PEG dengan lama perendaman 12 jam menunjukkan adanya perbedaan nyata 
dengan perlakuan aquades 48 jam. Aquades pada bahan invigorasi dinilai dapat memperbesar tekanan turgor sejalan dengan lamanya perendaman benih. Hal ini dapat dilihat pada penurunan nilai indeks vigor secara drastis pada perendaman aquades 24 jam dengan aquades perendaman 48 jam. 24 jam dinilai merupakan perendaman yang optimal untuk aquades. Pecahnya kulit benih akibat tekanan turgor dapat menyebabkan imbibisi secara tidak terkendali yang dapat mengganggu metabolisme benih dan menghambat perkecambahan (Nurmauli dan Nurmiaty, 2010).

Pada tolok ukur berat kering kecambah normal, nilai tertinggi terdapat pada perlakuan bahan invigorasi menggunakan $\mathrm{KNO}_{3}$ dengan lama perendaman 48 jam yang berbeda nyata terhadap perlakuan air kelapa 24 jam. Pada dasarnya benih dengan metabolisme yang baik akan meningkatkan akumulasi nilai berat kering (Nurussintani, 2012), sehingga dapat dilihat bahwa $\mathrm{KNO}_{3}$ dengan lama perendaman yang tepat dapat merombak cadangan makanan didalam benih lebih efisien dibandingkan dengan benih yang diberi perlakuan air kelapa lebih rendah dibandingkan dengan $\mathrm{KNO}_{3}$. Sedangkan pada berat basah kecambah normal pada perlakuan $\mathrm{KNO}_{3} 48$ jam berbeda nyata. Perbedaan yang terjadi pada $\mathrm{KNO}_{3}$ dan air kelapa sama halnya pada tolok ukur berat kering kecambah normal, karena jumlah kecambah normal yang diperoleh jauh lebih tinggi pada perlakuan $\mathrm{KNO}_{3}$ dibandingkan dengan perlakuan lainnya mempengaruhi berat basah kecambah normal. Sedangkan pada perlakuan $\mathrm{KNO}_{3} 12$ jam diduga karena larutan belum berimbibisi sepenuhnya kedalam benih sehingga menghambat perkecambahan normal. Proses imbibisi dapat memacu hormon giberelin yang berada pada lapisan aleuron untuk mendorong aktivitas enzim yang berperan dalam merombak zat makanan yang terdapat pada kotiledon ataupun endosperm (Azhari, 1995).

\section{SIMPULAN DAN SARAN}

Bahan invigorasi terbaik terdapat pada PEG. Lama perendaman tidak berpengaruh terhadap viabilitas benih padi kadaluarsa. Kombinasi perlakuan terbaik antara bahan invigorasi dan lama perendaman terdapat pada perlakuan PEG dengan lama perendaman 24 jam.

Perlu dilakukan penelitian lebih lanjut mengenai bahan invigorasi $\mathrm{KNO}_{3}$ dengan konsentrasi yang lebih ditingkatkan dan waktu perendaman 24-48 jam untuk perlakuan terbaik.

\section{DAFTAR PUSTAKA}

Amstrong, H. dan M.B. McDonal. 1992. Effects of osmoconditioning on water uptake and electrical conductivity in soybean seeds. Seed Sci. And Technol. 20:391-400.

Azhari, S. 1995. Hortikultura Aspek Budidaya. UI Press, Jakarta.

Badan Pengkajian Teknologi Pertanian Aceh. 2013. Pengelolaan Sumber Daya Genetik Tanaman Pangan Di Provinsi Aceh. BPTP Aceh.

Badan Pusat Statistik. 2017. Luas Panen, Produktivitas, dan Produksi Tanaman Padi Nasional. Http://bbpadi.litbang.pertanian.go.id/ Diakses tanggal 22 Maret 2018.

Copeland, L. O., M. B. McDonald. 2001. Principles of Seed Science and Technology. Fourth edition. Kluwer Academic Publishers. Boston, Dordrecht, London. 467p.

Darmadi, Didi., Iskandar Mirza. 2016. Inventarisasi dan koleksi eksitu sumber daya genetik tanaman spesifik aceh di kebun balai pengkajian teknologi pertanian banda aceh. Dalam Prosiding Seminar Biotik. Balai Pengkajian Teknologi Pertanian Aceh, Banda Aceh. Hal: 244-251. 
Erinnovita, M. Sari, D. Guntoro. 2008. Invigorasi benih untuk memperbaiki perkecambahan kacang panjang (Vigna unguiculata Hask. ssp. sesquipedalis) pada cekaman salinitas. Bul. Agron. 36:214-220.

Ernawati, P. Rahardjo dan B. Suroso. 2017. Respon benih cabai merah (Capsicum annum L.) kadaluarsa pada lama perendaman air kelapa muda terhadap viabilitas, vigor dan pertumbuhan bibit. Jurnal Agritop. 15(1):71-83.

Farooq, M., S. M. A. Basra, K. Hafeez. 2006. Seed invigoration by osmohardening in coarse and fine rice. Seed Sci. and Technol. 34 : 181-187.

Farooq, M., S.M.A. Basra, B.A. Saleem, N. Nafees, S.A. Chishti. 2005. Enhancement of tomato seed germination and seedling vigor by osmopriming. Pak. J. Agri. Sci. 42:36-41.

Fatimah, S. N. 2008. Efektivitas Air Kelapa dan Leri terhadap Pertumbuhan Tanaman Hias Bromelia (Neoregelia carolinae) pada Media yang Berbeda. Fakultas Keguruan dan Ilmu Pendidikan Universitas Muhammadiyah Surakarta.

Gunawan, A. 2004. Invigorasi Benih Bengkuang Kadaluarsa (Pachyrrhizus erosus L.) kadaluarsa dengan teknik Hydropriming menggunakan air kelapa muda dan pengaturan lama inkubasi. Skripsi. Fakultas Pertanian Universitas Syiah Kuala, Banda Aceh.

Ilyas, S. 1995. Perubahan Fisiologis dan Biokimia Benih dalam Proses Seed Conditioning. Keluarga Benih. No : 2

Maemunah, E. Adelina dan I.Y. Daniel. 2009. Vigor Benih Kakao (Theobroma cacao L.) Pada Berbagai Lama Penyimpanan dan Invigorasi. J. Agroland., 16 (3): 206-212.

Michael, B.E., and M.R. Kaufmann. 1973. The osmotic potencial of polyethylen glycol 6000 . Plant Physiol. 51: 914-916.

Mugnisyah WQ. 2007. Teknologi Benih. Universitas Terbuka, Jakarta.

Muthiah. 2013. Pengaruh Jenis Ekstrak dan Lama Inkubasi terhadap Viabilitas dan Vigor

Benih Cabai (Capsicum annum L.) Kadaluarsa. Skripsi. Program Studi Agroteknologi. Fakultas Pertanian. Universitas Syiah Kuala.

Nurmauli dan Y. Nurmiaty. 2010. Studi metode invigorasi pada viabilitas dua lot benih kedelai yang telah disimpan selama sembilan bulan. Jurnal llmu Pertanian Indonesia. 15(1): 20-24

Nurussamawati. 2014. Pengaruh perlakuan pra perkecambahan terhadap proses invigorasi benih padi kadaluarsa melalui teknik osmoconditioning. Skripsi. Program Studi Agroteknologi, Fakultas Pertanian Universitas Syiah Kuala, Banda Aceh.

Nurussintani, W., Damanhuri dan S.L. Purnamaningsih. 2012. Perlakuan pematahan dormansi terhadap daya tumbuh benih 3 varietas kacang tanah (Arachis hypogaea). Jurnal Produksi Tanaman.1(1): 86-93.

Prasetiyo. Y., T. (2006). Budidaya Padi Sawah TOT. Yogyakarta: Kanisius.

Rahardjo. P. 1986. Penggunaan Polyethylene Glycol (PEG) Sebagai Medium Penyimpanan Benih Kakao (Theobroma cacao L.). Pelita Perkeb., 2 (3):103-108.

Roberts E.H., R.D. Smith. 1977. Dormancy and the pentose phosphate pathway. P. 385-406. In A.A Khan (ed) The Physiologi and Biochemestry of seed dormancy and germination. North Holan publishing Company Amsterdam. New York Oxford.

Ruliansyah, Agus. 2011. Peningkatan Performansi Benih Kacangan Dengan Perlakuan Invigorasi. J. Tek. Perkebunan \& PSDL. Vol. 1, hal 13-18. Universitas Tanjungpura. Pontianak.

Soejadi dan U. S. Nugraha. $2002^{\mathrm{b}}$. Pengaruh perlakuan pematahan dormansi terhadap daya berkecambah benih padi. Hal 155-162. Dalam Murniati, E. et al (Eds.). Industri Benih 
di Indonesia. Laboratorium Ilmu dan Teknologi Benih, Budidaya Pertanian, Fakultas Pertanian, IPB. Bogor.

Utomo, B. 2006. Ekologi Benih. USU Repository, Medan.

Yari, L., A. Zareyan, F. Hasani, H. Sadeghi, S. Sheidaie. 2012. Germination and seedling growth as affected by presowing PEG seed treatments in (Oryza sativa L.). Tech. J. Engin. App. Sci. 2:425-429.

Zanzibar, M., dan S. Mokodompit. 2007. Pengaruh perlakuan hidrasi-dehidrasi terhadap berbagai tingkat kemunduran perkecambahan benih damar (Agathis loranthifolia $\mathrm{F}$. Salisb) dan mahoni (Swietenia macrophylla King). Jurnal Penelitian Hutan Tanaman 4 (1): 1-67. 